\title{
THE ROLE OF THE COURT IN SIMPLIFYING THE TRIABLE ISSUES AT PRE-TRIAL CONFERENCE*
}

AFTER twenty-three pre-trial conferences during a two year period, ${ }^{1}$ counsels' disagreement over the definition of triable issues in a "big" anti-trust suit prompted the pre-trial judge in a federal court to resolve the impasse by filing a pre-trial order in which he imposed his view of the issues on the parties.? The plaintiff, dissatisfied with the judge's delimitation of the issues, insisted that the court has no power to rule on the propriety of the issues which a party tenders as triable, and that simplification of issues under Federal Rule 16 requires voluntary accord of the parties. ${ }^{3}$ The language of Rule 16,4 which au-

*Life Music, Inc. v. Broadcast Music, Inc, 6 Fed. Rules Serv. 2d 16.21, Case 1 (S.D. N.Y. 1962).

1. Life Music, Inc. v. Broadcast Music, Inc, 6 Fed. Rules Serv. 2d 16.21, Case 1, at 1 (S.D.N.Y. 1962).

2. Id. at 9. Although the parties did reach agreement as to three issues, they reached only partial agreement on particularization of the major issue posed by the suit: whether the defendants had conspired to restrain plaintiff from entering the business of licensing performance rights in musical compositions. Issue No. 2 sets forth a general statement of the alleged conspiracy and, according to plaintiff, should contain twenty-six subdivisions, all issues for trial, delineating the means by which the alleged conspiracy was effectuated. The identity of language employed by defendants' tender of issues indicates that they concurred as to the validity of the general paragraph and the first four subdivisions, (a) through (d), of Issue No. 2. However, the defendants contested the validity, as issues relevant to the suit, of the other twenty-six subdivisions, (e) through ( $z$ ). These latter twenty-two "issues" were eliminated by the pre-trial judge. Judge Edelstein also accepted the defendants' tender of Issue No. 3 over the formulation of Issue No. 3 offered by the plaintif. Iife Music, Inc. v. Broadcast Music, Inc, Civil No. 106-159, S.D.N.Y., July 24, 1962, pp. 31-53 (Judge Edelstein's detailed analysis of the issues is omitted from the excerpt of the opinion reprinted in Federal Rules Service).

A Petition for a Writ of Mandamus was served on the Judge, returnable Octobar 8, 1962. The Petition challenges the authority of a pre-trial judge to frame the triable issues absent agreement of counsel. Letter to the Yale Law Joumal from MIr. Steve Ronai, Clerk to Judge David N. Edelstein, September 20, 1962. The hearing on that petition was held on October 15, 1962.

As this Note went to press, the Second Circuit Court of Appeals, relying on Brinn v. Bull Insular Lines, note 8 infra, denied the writ of mandamus. Life Mfusic, Inc. v. Honorable David N. Edelstein, Civ. No. 27791, 2d Cir., Oct. 30, 1962 (per curiam). The court found that Fed. Rule 16 does not require agreement in the sense of a formal assent by the parties. Rather the pre-trial judge may imply agreement where he concludes no genuine issue of fact or law is present, notwithstanding the fact that a party challenges the judge's formulation.

3. Life Music, Inc. v. Broadcast Music, Inc., 6 FED. Rules SERv. 20. 16.21, Case 1, at 9 (S.D.N.Y. 1962) ; Section A of petitioner's Brief in Support of Petition for Writ of Alandamus, p. 8, argues that the respondent-Judge Edelstein improperly defined the issues in the absence of agreement.

4. FED. R. CIv. P. 16:

Pre-Trial Procedure; Formulating Issies

In any action, the court may in its discretion direct the attorneys for the parties to appear before it for a conference to consider 
thorizes the pre-trial conference, does not specifically delegate the power to a court to simplify issues for trial, absent agreement of counsel. Indeed, there is virtually no support for such an action in the voluminous literature on the stubject, which proceeds on the hypothesis that agreement will be obtained on narrowing the issues. 5 Nevertheless, Judge Edelstein confidently concluded:

I have no doubt that the court has the power and the authority to define the issues where counsel have failed to agree as to what are the triable issues. $^{6}$

This decision thus raises the question whether a federal judge in pre-trial conference has the power to define unilaterally the issues for trial, and if so, under what circumstances should such power be exercised.

In spite of extensive judicial interpretation of Rule 16, the principal case appears to be the first in which a pre-trial judge expressly assumed the power

(1) The simplification of the issues;

(2) The necessity or desirability of amendments to the pleadings;

(3) The possibility of obtaining admissions of fact and of documents which will avoid unnecessary proof;

(4) The limitation of the number of expert witnesses;

(5) The advisability of a preliminary reference of isstues to a master for findings to be used as evidence when the trial is to be by jury;

(6) Such other matters as may aid in the disposition of the action.

The court shall make an order which recites the action taken at the conference, the amendments allowed to the pleadings, and the agreements made by the parties as to any of the matters considered, and which limits the issues for trial to those not disposed of by admissions or agreements of counsel ; and such order when entered controls the subsequent course of the action, unless modified at the trial to prevent manifest injustice. The court in its discretion may establish by rule a pre-trial calcndar on which actions may be placed for consideration as above provided and may either confine the calendar to jury actions or to non-jury actions or extend it to all actions.

5. Life Music, Inc. v. Broadcast Music, Inc., 6 FEd. RuLES SERv. 2d 16.21, Case 1, at 3-4 (S.D.N.Y. 1962) :

Although the literature on protracted cases is replete with procedures and suggestions based on the hypothesis that agreement will be obtained, nowhere have I found any discussion of the eventuality which now faces this court except for some mention by Judge William F. Smith of the Third Circuit that agreement as to what are the triable issues may not be always forthcoming. NYU Seminar, 21 FRD at 458. The suggested approach there was to incorporate the areas of agreement into a preliminary pre-trial order and hope that subsequent pre-trial conferences will be more productive. ... This alternative is, of course, less satisfying than a complete definition of the issues, and is in effect a compromise with the goals of pre-trial in protracted cases.

A New York attorney, outlining pre-trial conference procedure, has reported the suggestion of a federal district judge that counsel may recommend the triable issues in a conference, but that the pre-trial judge should actually formulate those issues, giving due consideration to the attorneys' suggestions. McAllister, Pre-Trial Practice in the Southern District of New York, 12 F.R.D. 373, 377 (1952).

6. Life Music, Inc. v. Broadcast Music, Inc., 6 Fed. Rules Serv. 20 16.21, Case 1, at 4 (S.D.N.Y. 1962). 
to define the triable issues without agreement of counsel. ${ }^{7}$ In so doing, Judge Edelstein relied upon Brinu v. Bull Insular Lincs, Inc., ${ }^{8}$ quoting the following from that decision:

If the pre-trial procedure is to have any meaningful purpose whatever, it is incumbent upon the court to narrow the issues reasonably and with discretion. ${ }^{9}$

The decision in Brinn, however, arose out of a motion to amend a pre-trial order to which the parties earlier had agreed. Although defendants argued that they "had not intended to agree that liability was admitted but only said so in a sort of 'without prejudice' position,"10 the parties had reached an apparent agreement at the time, and the resultant pre-trial order, once filed, could have been amended only if "manifest injustice" would occur." The court's response to defendants' motion made it clear that it did not see any possibility of "manifest injustice" occurring. ${ }^{12}$ Instead of merely disallowing the amendment, as it was free to do, the court decided to remove the phrase "by agreement" from its pre-trial order, and to "direct that the trial of that case is limited to those issues by order of the court." 13 Although this language might be construed as reflecting a belief that it was within the court's power to narrow the issues for trial without agreement of counsel, the fact that counsel initially stipulated the existence of liability, and that the pre-trial order was drawn accordingly, parries the thrust of the court's words in the Brinn case. Thus, its value as precedent for the action taken in the principal case is highly questionable.14

The absence of direct support both in the case law and the literature for the exercise of such a power by the pre-trial judge might indicate an understanding that agreement must be obtained if issues are to be simplified in the pretrial conference. ${ }^{15}$ Certainly, the relevant portion of Rule 16, which places great emphasis on agreement, reinforces such a conclusion :

7. But see Cannon Engineering Co. v. Merando, Inc, 250 F.2d 421 (D.C. Cir. 1957), a very brief, and ambiguous per curriam decision which might be an example of a pre-trial judge restricting the issues unilaterally.

8. 28 F.R.D. 578 (E.D. Pa. 1961).

9. Life Music, Inc. v. Broadcast Miusic, Inc., 6 Fed. Rules Senv. 2d 16.21, Case 1, at 4, quoting from Brinn v. Bull Insular Lines, Inc., supra note 8, at 579.

10. Brinn v. Bull Insular Lines, Inc., supra note 8, at 579.

11. The trial court may modify the pre-trial order "to prevent manifest injustice" Fed. R. Civ. P. 16. See generally 3 Moore, Federal Practice f 16.20, at 1130 (2d ed. 1948).

12. Brinn v. Bull Insular Lines, Inc, 28 F.R.D. 578 (E.D. Pa. 1961).

13. Id. at 579.

14. The court in the principal case also relied upon Package Machinery Co. v. Haysser Mfg. Co., 164 F. Supp. 904 (E.D. Wis. 1958), aff'd, 266 F.2d 56 (7th Cir. 1959). That case, however, dealt with the pre-trial judge's power to compel disclosure at the conference. The judge's order striking the complaint was issued under FED. R. CIv. P. 37(b) (2) (iii) when plaintiff failed to set forth its claimed trade secrets, as the court had ordered, so the issues could be defined.

15. One decision expressly recognizes this understanding by providing that if counsel cannot agree on a pre-trial order, pre-trial orders representing the views of both sides should be submitted to the trial court. Burton v. Weyerhaeuser Timber Co., 1 F.R.D. 571, 572-73 (D. Ore. 1941). 
The court shall make an order which recites the action taken at the conference, the amendments allowed to the pleadings, and the agreements made by the parties as to any of the matters considered, and which limits the issues for trial to those not disposed of by admissions or agracments of counsel. ... ${ }^{16}$

On the other hand, the lack of discussion of the court's power to simplify the issues, absent agreement of counsel, might merely reflect an optimistic belief that agreement will be obtained eventually. If emphasis is placed on the fact that neither precedent nor Federal Rule 16 expressly proscribes the particularization of issues by the court where counsel fail to agree, ${ }^{17}$ then the path Judge Edelstein advocates might be considered open and proper.

Similarly, an analysis of the purpose and philosophy of Rule 16 does not conclusively determine whether the judge's formulation of issues in the pretrial conference, without consent of counsel, is warranted. The purpose of the conference envisioned in Rule 16 is to achieve justice economically and promptly without transgressing the Anglo-American tradition of full, adversary trial of all genuinely disputed issues. ${ }^{18}$ The underlying philosophy of the conference represents a departure from the concept of litigation as a totally adversary contest in which technicalities and procedural devices are justified if they serve the purpose of victory. Since the conference is designed to streamline the dispute for trial by bringing the parties together for an informal inquiry into the facts and legal issues, its effectiveness hinges on the element of cooperation. ${ }^{10}$ The candid give-and-take atmosphere at pre-trial conference is a strong deterrent to insistence by counsel on points they know are of little value to the ultimate disposition of the litigation; moreover, this atmosphere often encourages settlement-one of the most important by-products of the conference.20 The assumption by the pre-trial judge of the power to define the triable issues may transform the conference into a contest in which the parties vie to gain court definition of the issues in their favor, thereby diminishing cooperation. On the other hand, in the particular case in which the judge exercises the power and resolves disagreement over the definition of triable issues, the actual trial will be simplified and the litigation more easily completed. Thus, the purpose and philosophy of Federal Rule 16 may be either furthered or frustrated by judicial exercise of power to define the triable issues.

The power of the pre-trial judge to define the triable issues may be found in the court's broad, inherent power over its own process, ${ }^{21}$ which can be involked

16. FED. R. CIv. P. 16. [Emphasis added.]

17. Life Music, Inc. v. Broadcast Music, Inc., 6 Fed. Rules Senv. 2d 16.21, Case 1, at 5 (S.D.N.Y. 1962).

18. See generally Murrah, Pre-Trial Procedurc-A Statement of Its Esscutials, 14 F.R.D. 417 (1954) ; NIMs, Pre-Trial 9-12 (1950); Clark, Summary and Conclusion To An Understanding Use of Pre-Trial, 29 F.R.D. 454 (1962).

19. Pharr, The Truth About Pretrial, 47 A.B.A.J. 177, $178-79$ (1961) ; Clark, Summary and Conclusion To An Understanding Use of Pre-Trial, 29 F.R.D. 454 (1962).

20. Nims, PRE-Trial 62 (1950).

21. Gumbel v. Pitkin, 124 U.S. 131, 144 (1888) ; MacAlister v. Guterma, 263 F.2d 65, 68 (2d Cir. 1958) ; Iink v. Wabash R. Co., 370 U.S. 626 (1962); see generally 1 Mooks, Federal Practice ff 0.60[6], at 612-14 (2d ed. 1948). 
at any time ${ }^{22}$ on the court's own motion. ${ }^{23}$ This inherent judicial power "to prevent abuses, oppression and injustice"24 has been exercised in various ways, ${ }^{25}$ including the dismissal of frivolous, ${ }^{26}$ sham ${ }^{27}$ claims, and the pretrial consolidation of actions and appointment of general counsel to manage the consolidated actions. ${ }^{28}$ In view of the expense and delay to a party forced to litigate false, uncontroverted issues, this inherent power may support a court's unilateral particularization of issues at the pre-trial conference. However, resort to inherent judicial power seems unnecessary, since specific support for Judge Edelstein's position, although not in Rule 16, may be found elsewhere in the Federal Rules. The conclusion that the judge may simplify issues for trial, absent agreement of counsel, is strengthened, under certain circumstances, by Rule $12(\mathrm{f})$, which allows the court, upon its own initiative at any time, to "order stricken from any pleading any insufficient defense or any redundant, immaterial, impertinent or scandalous matter."20 There is little reason why the freedom given the judge under Rule $12(\mathrm{f})$ to pare such matter from the pleadings should not be available to define the triable issues at the pre-trial conference. For the resultant pre-trial order is essentially an claboration on the pleadings. The pleadings pass out of the picture, and the pre-trial order assumes the role otherwise played by the pleadings. ${ }^{30}$ Of course, if the pre-trial order is brief, it may not fully supersede the pleadings, making resort to them still necessary. ${ }^{31}$ But even in that situation, the pleadings and the pretrial order will complement each other; the pre-trial order still can be viewed as an extension of the pleadings. Thus, Rule 12(f) should be authority for unilateral action by the judge where the matter involved would have been amenable to a motion to strike under Rule 12(f). For example, this would permit a pre-trial judge to eliminate as "immaterial" factual matter which, although disputed, would not support a claim or defense, even if proven ; 32 it

22. King of Spain v. Oliver, 14 Fed. Cas. 577, 578 (No. 7,814) (C.C.D. Pa. 1810), where the inherent power was invoked even before filing of the declaration.

23. O'Connell v. Mason, 132 Fed. 245, 247 (1st Cir. 1904).

24. Gumbel v. Pitkin, 124 U.S. 131, 144 (1888).

25. See 1 Moore, Federal Practice $\int 0.60[6]$, at 612-14 (2d cd. 1948).

26. O'Connell v. Míason, 132 Fed. 245, 247 (1st Cir. 1904).

27. Cunha v. Anglo Calif. Nat'l Bank, 34 Cal. App. 2d 383, 93 P.2d 572 (1939).

28. MacAlister v. Guterma, 263 F.2d 65, 68 (2d Cir. 1958).

29. FED. R. CIV. P. 12(f).

30. Fed. R. Crv. P. 16. Healing v. Jones, 174 F. Supp. 211, 220 (D. Ariz. 1959); The Pre-Trial Order, 4 Fed. Rules Serv., Commentary, 16.3, at 905-06 (1941).

31. Plastino v. Mfills, 236 F.2d 32 (9th Cir. 1956), in which the court stated: [I]t may be observed that nothing is gained by bidding "good-bye" to the pleadings if the pre-trial order is a poorer product than the pleadings.

\section{Id. at $34 \mathrm{n}: 1$.}

32. In the principal case, Judge Edelstein refused to include, as triable issues, facts which would not have supported plaintiff's claim for relief, even if resolved in its favor. For example, see proposed subdivisions (h) and (i) of Issue No. 2. Life Music, Inc. v. Broadcast Music, Inc., Civil No. 106-159, S.D.N.Y., July 24, 1962, pp. 38-39. Here the pretrial judge's action is similar to sustaining a motion to dismiss a complaint for failure to state a claim upon which relief can be granted, but, of course, his action would center on 
would also authorize the striking of redundant matter from the pre-trial order ${ }^{\text {an }}$

Courts generally have not favored extensive use of motions to strike, often denying them even though the matter attacked is prolix, superfluous, and false. ${ }^{34}$ This reluctance to disturb the pleadings is probably justified when the decision on the motion must be made on the basis merely of the pleadings, brief memoranda, and a short hearing; otherwise, a party might be denied the opportunity to pursue a matter which, although it appears barren in the skeletal framework of the pleadings, possibly could afford relief when the full extent and theory of the action is developed. However, if the power to strike is invoked in the context of a responsible, thorough pre-trial conference, the dinger of judicial mistake due to unfamiliarity with the case is minimized. In view of the prejudice to parties forced to litigate immaterial issues, and the public interest in efficient justice, it is desirable that the use of Rule $12(f)$ in the pretrial conference not be restricted by the doctrinal swaddling which has enveloped the motion. Rather, the judge should be given considerable discretion in determining what is "redundant, immaterial or impertinent" because of the unique vantage point afforded him by the conference process.

The provision for summary judgment in the Federal Rules also should justify the elimination of certain issues by the judge at the pre-trial conference. Rule 56 provides for partial summary judgment on matters of law where "material facts exist without substantial controversy."as Because judicial action

one issue only and not the entire complaint, and the judge would act on his own initiative. Under Rule 12(f), the tender of such an issue would be "immaterial" to the success of the action. Conversely, since Rule 12(f) explicitly authorizes a judge to strike an "insufficient defense" from any pleadings, this logically authorizes such action in the pre-trial conference. Thus, the pre-trial judge should have the power to throw out not only insufficient claims as Judge Edelstein did in the principal case, but the tender of an issue which, although factually disputed, would not sustain defensive victory as a matter of law.

33. Judge Edelstein refused to adopt, as issues for trial, formulations offered by the plaintiff which amounted to vague re-wording of the basic issues upon which the partics had manifested agreement. For example, see proposed subdivision (u) of Issue No. 2 , id. at 47-48. Such redundancy is specifically condemned by Rule $12(\mathrm{f})$.

34. Boerstler v. American Medical Ass'n, 16 F.R.D. 437 (N.D. Ill. 1954); Radtke Patents Corp. v. C. J. Tagliabue Mfg. Co., 31 F. Supp. 226 (E.D.N.Y. 1939) ; Kratus v. General Motors Corp., 27 F. Supp. 537 (S.D.N.Y. 1939); 2 MOoRE, Federul Puactict II 12.21, at 2317 (2d ed. 1948). But see Hershel Calif. Fruit Prods. Co. v. Hunt Foods, Inc., 16 F.R.D. 547 (N.D. Cal. 1954), where the complaint in an antitrust suit was stricken in its entirety because it was not a short and plain statement of the cham, therefore grossly violating FED. R. Crv. P. 8.

35. Fed. R. Crv. P. 56(d). Subdivisions (a) and (b) allow a party to move for summary judgment on part of a claim or defense.

Holcomb v. Aetna Life Insurance Co., 255 F.2d 577, 580 (10th Cir. 1958), authorizes summary judgment during the pre-trial conference. Similarly, in United States v. Jeffers, 90 F. Supp. 356, 358 (D. Ore. 1950), Judge Fee reserved a motion for summary judgment for the pre-trial conferences where the propositions of fact would be formulated. There are numerous examples of summary judgment being granted as a result of the pre-trial order. See Berry v. Spokane, P. \& S. Ry., 2 F.R.D. 483 (D. Ore. 1942); and Lynch v. Call, 261 F.2d 130, 132 (10th Cir. 1958). 
under Rule 56 requires a motion by counsel, ${ }^{36}$ arguably the pre-trial judge may not act on his own initiative where there is no motion for summary judgment pending. In the informal conference context, however, the ceremony of requiring a motion should be dispensed with. The judge need merely suggest that the proper party move for summary judgment, and thereby authorize his own initiative. As long as a party does not object upon receiving notice from the court that it sees no substantial issue of fact, it can reasonably be assumed that he would, if asked, fulfill the ceremony of making a formal motion. The situation in which both parties object would probably be infrequent. ${ }^{37}$ Should it arise, however, the problem of whether the pre-trial judge should be authorized to take the initiative in awarding, in effect, partial summary judgment would be squarely presented. In that case, there is less justification for the court's unilateral action, since neither party could claim prejudice resulting from the delay and expense inherent in the pursuit of issues susceptible to decision without trial. Nevertheless, the decision of law, whether given at pre-trial conference or at trial theoretically should be the same, and the fact that the parties believe it in their interest to litigate the issue should not be allowed to outweigh the economies obtained through immediate resolution of uncontroverted issues. The right to appeal the decision is the same regardless of when it is made; partial summary judgment can be appealed only after final judgment is rendered. ${ }^{38}$ Moreover, the role of the pre-trial judge is not the passive one he plays when the case is prepared for trial merely on the basis of pleadings; rather, the judge has the task of ensuring correct preparation of the case for actual trial. It would frustrate the purpose of Rule 16 if the parties could force the pre-trial judge to leave for the trial judge, with consequent duplication of effort, an issue capable of immediate determination. ${ }^{30}$.

But the pre-trial judge is not always confronted with the convenient situation where the entire issue insisted upon by one or both of the parties can be struck as repetitive or totally immaterial, or is susceptible to immediate decision.

36. FED. R. CIV. P. 56 (a) and (b).

37. This situation might arise if both parties were unsure of victory on the issue of law and preferred to wait until trial for a decision, thus obtaining, in some instances, a different judge to resolve the issue. However, the pre-trial judge should be able to break such an impasse by indicating in advance which way he believes he will rule. Another situation in which both parties object may be presented when a jury trial is involved. Although one party may realize he could receive summary judgment, for example, on the issue of liability, he may prefer to go to trial and prove liability because of the psychological impact it could have upon the jury in their estimation of damages.

38. 6 Moore, Federai Practice If 56.20[3], at 2300-02 (2d ed. 1948).

39. The same reasoning supports the conclusion that the pre-trial judge should be free even to resolve a factually controverted issue involving solely documentary evidence, as long as no jury trial is demanded. Of course, the conference judge may not resolve an issue on depositions if there is a possibility of live testimony at the actual trial; but when there is no such possibility, it would be uneconomical if the pre-trial judge, who has spent valuable time exploring in detail the isșues, was not allowed to utilize his knowledge of the particular issue and proceed to a decision. Otherwise, it would be necessary to totally re-develop the issue at trial. 
Instead, counsel might persist in tendering a valid issue in vague and openended form. ${ }^{40}$ Lack of adequate preparation for the conference often accounts for this result. ${ }^{41}$ However, it may also be due to a reluctance on the part of counsel to commit themselves to a clearly defined path at an early stage in the litigation. ${ }^{42}$ Counsel may be unsure of the basis of their causes of action, even after preparation, and may hope, by couching the issue in vague, all-inclusive language, to keep the scope of discovery and trial very broad. If the pre-trial judge is unable to induce precision in the definition of the issues by the parties, the purpose of the conference will be partially frustrated. Thus, the pre-trial judge would seem justified in restating such an issue to the extent that dis= closure and discussion at the conference make it clear that the matter he pares off is "redundant, immaterial or impertinent," or that an issue on which he gave immediate judgment presents no "genuine issue of fact." The task of rewording vague and open-ended issues so as to eliminate Rule $12(\mathrm{f})$ material and decide Rule 56 issues, however, is an especially delicate one which illtustrates the importance of two obligations the judge should assume when he undertakes to simplify the issues. Before unilateral action is taken, it should be incumbent upon the court to afford adequate notice of the action contemplated so that the parties may prepare and present their views. Also, the pre-trial judge should articulate in the pre-trial order what issues or matter he has eliminated through Rules 12 (f) and 56 power, and what sistes were stipulated by the parties so that the litigants are in no way prejudiced in their right to have the judgment reviewed. This is particularly important in the case of rewording vague and open-ended formulations, for it is only through careful labeling by the judge of what he has deleted that an appellate court can fully understand the action taken.

The general proposition that no disputed issues of fact should be eliminated by the judge in pre-trial conference seems indisputable in view of our commitment to the adversary process, the success of which is dependent on full trial of all such issues. But the determination of what matter constitutes a genuine issue for trial is not always an easy one; indeed, this question is precisely what was in conflict at the conference in the principal case. However, judges have long determined, under Rules $12(f)$ and 56 , whether certain facts or issues warrant trial; this determination would not seem any more difficult at pre-trial conference-indeed, the risk of judicial error is less, since the judge should be more familiar with the case. Since the proper application of those powers in the conference context should not result in the removal from trial of any disputed issues of fact that are legally operative, full adversary trial of such issues

40. An example of this in the principal case is the plaintiff's tender of Issue No. 3. Life Music, Inc. v. Broadcast Music, Inc., Civil No. 106-159, S.D.N.Y., July 24, 1962, 1p. 51-53.

41. Report adopted by the Judicial Conference of the United States, Procedure in AntiTrust and Other Protracted Cases, 13 F.R.D. 62, 67 (1951).

42. Ibid. Report adopted by the Judicial Conference of the United States, Handbool: of Recommended Procedures for the Trial of Protracted Cases, 25 F.R.D. 351, 388 (1960). 
will not be infringed upon. Moreover, the pre-trial conference itself remains adversary in the sense that counsel must persuade the judge whether or not to invoke Rules $12(f)$ and 56 power. Indeed, the primary argument against the judge's use of such a power is that it may so emphasize the adversary process in the conference that legal skirmishing will prevail, to the detriment of cooperative discussion in the conference. If the conference is to effectively achieve its purposes, ${ }^{43}$ some of which necessitate voluntary agreement, the element of cooperation is essential-so essential that it can be argued that any power to simplify or define the issues should be denied the judge. The danger that the mere existence of such a power will stifle cooperative discussion, however, must be carefully weighed against the advantage of judicial efficiency in the specific instances where the pre-trial judge invokes his Rules $12(f)$ and 56 power. Recognition that the pre-trial judge may, to some degree, define the triable issues, has the other advantage of serving as a stimulus to attorneys to prepare adequately for the conference. Cooperation is valueless if counsel come unprepared, or send subordinates who not only know little about the case, but also lack the authority to make admissions or agreements. if In view of the advantages accruing from the existence and occasional use of such a power to simplify the issues, the pre-trial judge should not be denied the power. But the emphasis of the conference should be upon voluntary accord. The attorneys should not be forced to carry on their discussion in the shadow of a judge anxious to impose his view of the issues on the parties. ${ }^{45}$ Only if counsel demonstrate a total inability to proceed effectively, as occurred in the principal case, ${ }^{10}$ should the judge, in order to resolve the impasse, unilaterally take steps to simplify and define the triable issues.

43. This includes matters independent of the simplification of the issues, such as admissions of documents and facts, limitations of expert witnesses, reference of issues for findings to a master, and "such other matters as may aid in the disposition of the action." FED. R. CIV. P. 16. Although there is debate as to whether settlement should be actively sought by the pre-trial judge, it is certainly an important by-product of the conference envisioned by Rule 16. See generally Nrars, Pre-TrIal 62 (1950).

44. Pharr, The Truth About Pretrial, 47 A.B.A.J. 177, 178 (1961); see note 41 supra.

45. Accordingly, Professor Moore states: "The court should not injpose on the parties its own views of what the issues are." 3 MLoore, Federal Practice $\llbracket 16.11$, at 1116 (2d ed. 1948).

46. Judge Edelstein, in the principal case, stated:

I have hesitated in the exercise of this power in order to afford counsel every opportunity to arrive at a definition which would be mutually acceptable.

Life Music, Inc. v. Broadcast Music, Inc., 6 Fed. Rules Serv. 2d 16.21, Case 1, at 5 (S.D. N.Y. 1962). 